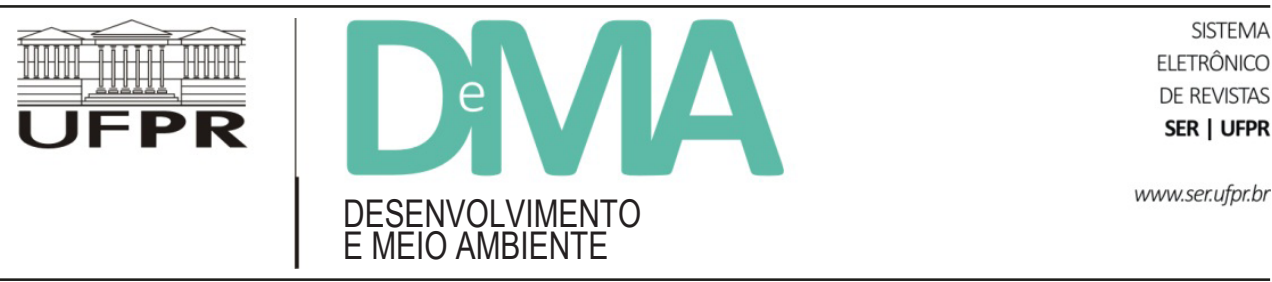

\title{
A saga do algodão no semiárido nordestino: histórico, declínio e as perspectivas de base agroecológica
}

\section{The cotton saga in the northeastern semiarid region: history, decline and the agroecological perspectives}

\author{
Luis Cláudio MATTOS ${ }^{1 *}$, Jorge Luiz Schirmer de MATTOS $^{1}$, Ricardo BLACKBURN², Fábio dos Santos \\ SANTIAGO$^{2}$, Jayme Bezerra de MENEZES NETO \\ ${ }^{1}$ Universidade Federal Rural de Pernambuco (UFRPE), Recife, PE, Brasil. \\ ${ }^{2}$ Diaconia, Recife, PE, Brasil. \\ ${ }^{3}$ Universidade Federal de Santa Maria, Santa Maria, RS, Brasil. \\ *E-mail de contato: 1cmattos@outlook.com
}

Artigo recebido em 15 de maio de 2020; versão final aceita em 18 de agosto de 2020, publicado em 18 de dezembro de 2020.

RESUMO: O cultivo do algodão no semiárido nordestino remonta ao período colonial no Brasil. Nas épocas áureas de produção, cumpriu importante papel na economia da região semiárida. Inicialmente, as lavouras de algodão localizavam-se próximas aos quintais das casas, destinadas à produção de fibra para as roupas dos escravos, bem como à produção de alimentos quando se associava o algodão com milho e feijão. Mais tarde, o cultivo de algodão se associou também à pecuária, gerando fibra, alimento para os animais e renda para a população local. O algodão teve seu apogeu no semiárido nos idos do século XX, quando ficou conhecido como o "ouro branco do Nordeste", até o seu declínio a partir dos anos 1980. No entanto, a partir do início do século XXI, iniciou-se um lento e progressivo processo de recuperação, agora em bases agroecológicas vinculadas à agricultura familiar e ao mercado de moda em nível mundial, com interesse crescente na fibra de algodão orgânica. Alguns aspectos que desafiaram a produção de algodão no passado ainda continuam instigando agricultores e agricultoras no presente. E é precisamente sobre estes aspectos que a revisão proposta nesse artigo visa tratar. Foram trazidos aqui autores clássicos e contemporâneos, além de algumas entrevistas com pessoas-chave envolvidas na retomada do algodão. O objetivo é fazer aflorar a multidimensionalidade da saga do algodão no semiárido nordestino, considerando-se as suas bases históricas, técnicas, sociológicas e mercadológicas para apontar caminhos que poderão contribuir com sua sustentabilidade futura.

Palavras-chave: algodão orgânico; agroecologia; sistema participativo de garantia; ouro branco do Nordeste; mercado de moda. 
ABSTRACT: The cotton has been cultivated in the northeastern semiarid region in Brazil since the colonial period. In the golden age of production, it played an important role in the economy of the semiarid region. Initially, cotton crops were located close to the backyards of the houses, mainly intended for producing fiber for the slave's clothing, as well as for the production of food when it was combined with corn and beans. Later on, cotton cultivation was also associated with livestock, generating fiber, food for animals and income for the local population. Cotton reached its peak during the 20th century, when it became known as the "white gold of the Northeast", until its decline in the 1980s. However, from the beginning of the 21 st century, it started a slow and progressive recovery process, now on an agroecological basis, linked to small farmers and the fashion market worldwide, with growing interest in organic cotton fiber. Some aspects that have challenged the cotton production in the past still continue to challenge farmers today. It is precisely on these aspects that this review aims to address. Classic and contemporary authors were brought here, as well as some interviews with key-people involved in the recent experiences with cotton. The objective is to bring out the multidimensionality of the cotton saga in the northeastern semiarid, considering its historical, technical, sociological and marketing aspects to point out ways that may contribute to its future sustainability.

Keywords: organic cotton; agroecology; participatory guarantee system; northeast white gold; fashion market.

\section{Introdução}

O semiárido nordestino está vivenciando um processo de renascimento da cultura do algodão. Sua história remonta aos idos do período colonial no Brasil, em que durante séculos o tripé algodão + gado + alimentos, juntamente com a cana-de-açúcar, sustentou a economia nordestina (Câmara, 1982). A partir do século XVIII, o cultivo do algodão alargou-se do sul da Comarca de Alagoas até os limites ocidentais da Capitania do Ceará, desde o litoral até o clima árido do distante Sertão (Palacios, 2004), até experimentar um declínio sem precedentes no último quarto do século passado. Contudo, desde o início da década de 2010 o número de unidades de produção da agricultura familiar no semiárido que vem se envolvendo nas experiências de produção tem saído da casa das dezenas para centenas (Lima, 2020) e já soma mais de 2.000 famílias (Textile Exchange, 2019). Esse processo de ressurgimento tem chamado a atenção de diversos profissionais, gestores públicos e instituições de pesquisa, além da classe política e pessoas comuns que ainda cultivam no imaginário os tempos em que o algodão era considerado o "ouro branco do Nordeste".

Uma conjunção de fatores tem proporcionado esse novo ciclo que, embora ainda tímido em extensão territorial, apresenta um engajamento consistente dos envolvidos ao longo de sua cadeia produtiva na região, que passou a se estabelecer em outros moldes produtivos e mercadológicos. Dentre esses fatores, pode-se incluir: i) a evolução do sistema de produção baseado nos princípios da Agroecologia; (ii) as inovações nos serviços de assistência técnica e extensão rural; (iii) o aumento da sensibilidade de pesquisadores de centros de pesquisa, como Embrapa e universidades, para buscar soluções acessíveis à agricultura familiar no semiárido; (iv) as mudanças na legislação de certificação de produtos orgânicos; (v) o desenvolvimento de equipamentos que permitem processar localmente o primeiro estágio do beneficiamento do algodão, o descaroçamento; e (vi) as oportunidades surgidas com as mudanças 
no mercado da moda e um crescente interesse pela fibra de algodão orgânico por parte de empresas ligadas às indústrias têxteis, às confecções e às redes de comércio justo.

Por conta disso, se faz necessária uma análise criteriosa desse novo capítulo da saga do algodão no semiárido nordestino, partindo-se de relatos históricos e contemporâneos de seu uso até os dias atuais, de modo a se compreender, em detalhes, esse fenômeno. Contudo, nossa intenção ao reconstituir a trajetória do algodão no semiárido brasileiro desde seus primórdios passa longe da pretensão de esgotar na sua totalidade os aspectos que, histórica e contemporaneamente, compõem esse tema. Assim, nos detivemos em reconstituir alguns elementos que nos ajudaram a recompor o contexto no qual se amparou a cotonicultura na região semiárida até a chegada desse novo ciclo do algodão, lançado mais recentemente em bases agroecológicas. A partir desses elementos, fizemos uma reflexão sobre alguns aspectos que consideramos importantes e que outrora desafiaram e continuam desafiando os produtores e as produtoras em termos produtivos e de comercialização para seguirem produzindo alimentos e gerando renda às famílias, tendo como produto principal o algodão.

Para esse exercício, optamos por fazer uma revisão de literatura, utilizando tanto bibliografias clássicas quanto especializadas, mas, também, nos amparamos em fontes secundárias e depoimentos de pessoas que vivenciaram algum dos eventos importantes da saga do algodão. Inicialmente, realizamos a leitura de documentos que trataram da trajetória histórica do algodão desde suas origens, passando pelo seu apogeu e decadência, para entender o papel central do algodão mocó até a chegada do "fantasma" do bicudo, considerado o principal vilão responsável pelo seu fim. Além da literatura, nos amparamos em entrevistas com algumas personagens-chave e em informações colhidas em relatórios das entidades que estão envolvidas nas experiências do algodão agroecológico em consórcio para compreendermos o processo de retomada do algodão no semiárido. Na sequência, tecemos algumas considerações no que diz respeito aos arranjos institucionais e tecnologias apropriadas para a nova concepção de cultivo do algodão para atender aos princípios agroecológicos e à demanda de uma indústria cada vez mais exigente em termos sociais e ambientais. Por fim, abordamos as potencialidades da certificação participativa na perspectiva da pluma do algodão agroecológico do semiárido ocupar novos nichos do mercado orgânico.

\section{Breve histórico do cultivo do algodão no semiárido nordestino}

O domínio do algodão pelos povos originários do Brasil vem desde os primórdios da colonização portuguesa (Mawe, 1812; Gardner, 1846; Sousa, 1879; Staden, 1930; Amaral, 1958). Sua exploração ocorreu inicialmente de forma marginal, não como cultivo de renda, mas para atender uma demanda local, pois serviu principalmente para a fabricação de panos grossos, destinados a vestir os escravos (Costa \& Bueno, 2004). Mesmo quando cultivado com interesses comerciais, o algodão se circunscrevia a cultivos no entorno das casas. E isso se deu graças ao uso de espécies nativas e exóticas, que foram sendo incorporadas paulatinamente ao cotidiano dos núcleos de colonização, marcando o início de sua expansão. Sua fiação e sua tecelagem eram feitas domesticamente, com instrumentos 
rudimentares. Esse fato chegou a ser, na época, objeto de interlocução dos jesuítas, que passaram a defender o envio de tecelões ao Brasil para que se pudesse fiar e tecer o algodão de forma mais eficaz (Costa \& Bueno, 2004).

A revolução industrial na Europa do século XVIII deu grande impulso à cotonicultura no Nordeste, inclusive com a introdução de novas espécies e cultivos com fins comerciais. Há registro de que as primeiras arrobas de algodão levadas de Pernambuco para Portugal datam de 1778 (Câmara, 1982). Isso demonstra que o Nordeste brasileiro desde muito cedo se integrou às cadeias da emergente indústria têxtil internacional.

Na região semiárida, o algodão se expandiu entre fins do século XVIII e início do século XIX associado à expansão da agricultura e da pecuária, em decorrência da ocupação colonial (Andrade, 1973). Os relatos mais antigos mencionam que as lavouras de algodão eram manejadas com mão de obra escrava na forma de policultivo, onde as espécies de valor alimentício tinham lugar privilegiado (Câmara, 1982):

[...] deve-se lhe plantar pelos intervalos legumes, como feijões, milho até mesmo mandioca, o que tudo deve plantar o agricultor de algodão, para fartura de sua casa; e nem estas plantações lhe danificam o seu algodoal, porque em pouco tempo se colhem e ficam os algodoeiros desafogados (Câmara, 1982, p. 130).

Foi então que, ao longo dos anos, um processo de hibridação com espécies nativas ancestrais lhe conferiu um caráter fenotípico próprio, de fibra longa, que se tornou um símbolo nordestino até a década de 1980, quando começou a sua decadência.

\subsection{Sistemas de cultivo de algodão mocó}

O cultivo de algodão no Nordeste brasileiro, em especial na região semiárida, por muitos anos esteve baseado no algodão mocó. Apesar de ser considerado por muitos como um algodão "nativo", trata-se na verdade de uma variedade de uma espécie exótica ${ }^{1}$, cuja origem é centro-americana (Moreira et al., 1989).

O sistema de cultivo desse algodão associava quatro elementos fundamentais para a convivência com o semiárido: (i) o fato de ser uma cultura de renda; (ii) estar associado aos cultivos alimentares, principalmente milho e feijão; (iii) interagir com a pecuária, principalmente com caprinos e bovinos, que conferiam à renda um componente de "poupança" a longo prazo; e (iv) interagir com as reservas de vegetação nativa via pastoreio sazonal (Andrade, 1973).

A esses elementos associavam-se outros, com segurança hídrica, obtida com a construção de poços e reservatórios em açudes, e suprimento energético, baseado fundamentalmente na lenha. E não menos importante era a disponibilidade de terra, com certa abundância, que se constituiu como elemento crucial para fazer prosperar os sistemas baseados no cultivo de algodão. Isso porque as propriedades de grandes extensões de terra permitiam não só o acesso aos meios de produção, como também compeliam aos que não as possuíssem (moradores

\footnotetext{
${ }^{1}$ Gossypium hirsutum L. r. marie galante Hutch é o algodão mocó, enquanto o Gossypium hirsutum L. r. latifolium Hutch é o algodão herbáceo, mais difundido. A única espécie verdadeiramente nativa do semiárido brasileiro é a Gossypium mustelinum Miers ex G. Watt, da região do Seridó, entre o Rio Grande do Norte e a Paraíba, também chamado de Gossypium caicoense, de fibra castanha.
} 
sem-terra) certas condições de vida, que lhes fosse compulsória sua integração como elemento de operação do sistema, trabalhando para os proprietários dessas terras. Esses moradores sem-terra tornaram-se meeiros na produção do algodão a quem cabia o cuidado com a produção e a colheita, da qual apenas tinham direito à metade. Por sua vez, havia o risco de perdas severas em anos de seca, amenizadas pela pecuária extensiva, capaz de agregar valor sem uso intensivo de mão de obra (Andrade, 1973).

Não obstante, o cultivo de algodão e a pecuária não eram atividades que competiam entre si. $\mathrm{Na}$ verdade, eram complementares, pois à medida que o algodoeiro servia de forragem ao gado, os animais retribuíam com esterco, fertilizando as terras para o próximo ciclo de cultivo. Para isso, o algodão era colhido no meio do período mais seco do ano, permitindo que o gado permanecesse nas áreas cultivadas por dois ou três meses, alimentando-se dos restos da cultura. Assim, havia incentivo aos grandes proprietários de terra para criarem gado, ao mesmo tempo em que eram estimulados a realizar o plantio do algodoeiro em parceria com os "moradores 2 " de suas terras. Os moradores, em geral, eram obrigados a vender sua parte da produção aos proprietários das terras em que trabalhavam. Isso permitia aos proprietários aumentar seus lucros, garantindo pasto em estações secas, ao mesmo tempo em que transferiam o risco da atividade agrícola para os "moradores", sem, no entanto, abrir mão dos lucros da colheita do algodão em anos de boas safras. Nessa relação, as perdas de safra eram convertidas em dívida, criando a dependência que os mantinha vinculados à terra alheia (Andrade, 1973).

Outro sistema praticado naquele período envolvia o algodão e os cultivos alimentares, tais como milho e feijão. Nesse caso, não ocorria competição entre os cultivos, pois assegurava-se que a semeadura fosse realizada de tal maneira que a floração dos cultivos de algodão, feijão e milho não coincidissem (Amaral, 1958).

Mesmo com a ameaça da seca, essa era a base da segurança alimentar das famílias locais, com ou sem-terra. Contudo, havia certa desvantagem para a maior parte das famílias sem-terra, pois o regime de meia $^{3}$ também vigia sobre esses produtos, o que lhes impunha um regime de maior insegurança alimentar (Almeida \& Parisius, 1995).

Do ponto de vista ambiental, o sistema de produção contava com a possibilidade do pousio. E mesmo a abertura de novas áreas de cultivo era feita principalmente com a prática da "broca e queima". Ademais, a semeadura feita "no toco" permitia uma recuperação mais rápida das propriedades do solo e da vegetação nativa sob sistemas itinerantes de rotação, pois, com a queima da floresta, ocorria a deposição de grandes quantidades de nutrientes (principalmente potássio, fósforo, nitrogênio e

\footnotetext{
${ }^{2}$ Com a decadência do trabalho escravo, parte da população escravizada se interiorizou e, sem nenhuma ajuda e sem terras para cultivar, transformou-se em "morador de condição", habitando choupanas de palha em propriedades rurais no semiárido. Eram considerados um tipo especial de assalariado pelos donos das terras, que muitas vezes trocavam trabalho por comida (Andrade, 1973).

${ }^{3}$ Regime em que metade da colheita pertence ao dono da terra e a outra metade a quem produz.

${ }^{4}$ Sistema de raleamento da vegetação e queima dos restos vegetais para permitir o plantio.

${ }^{5}$ Eram chamados de plantios "de toco" ou "no toco" aqueles em que uma área de capoeira ou caatinga secundária era desbastada e, após o uso do fogo, os tocos de árvores e arbustos não eram todos retirados, permitindo uma rápida rebrota. Os tratos culturais eram em sua maioria realizados manualmente.
} 
cálcio), causando aumento considerável do $\mathrm{pH}$ do solo, tornando-o ligeiramente alcalino, ainda que temporariamente, mas o suficiente para reduzir consideravelmente a toxidez do alumínio solúvel, cujos efeitos persistiam por até três anos (Fernandes et al., 1992).

A queima, por um lado, contribuía para uma redução drástica nos indicadores biológicos do solo, para a desorganização do equilíbrio populacional da fauna do solo e para a redução da diversidade da fauna edáfica, especialmente no primeiro ano após a queima. A recuperação das condições originais do solo exigia maior tempo da área em pousio do que em cultivo, embora esse processo de recuperação já se fizesse notar nos indicadores químicos, físicos e biológicos a partir do quinto ano da regeneração. $\mathrm{Na}$ medida em que o algodão mocó era conduzido de forma a se tornar semiperene, o pousio cumpria o papel de restauração ecológica, de modo que o algodão, crescendo em meio ao processo de recuperação gradual da caatinga, a ela se incorporava. Assim, a abundância de terras permitia que os cultivos tradicionais de algodão mocó levassem até 10 anos para retornar à mesma área (Nunes et al., 2006).

O declínio do sistema de produção de algodão mocó começou com a intensificação do uso da terra, decorrente principalmente da repartição da propriedade entre herdeiros. As terras passaram a ser destocadas, criando os chamados "cultivos no limpo", com alongamento do período de cultivo em função do aumento do número de ciclos anuais. Com efeito, isso reduziu o número e a duração dos pousios que, em casos extremos, devido às pequenas extensões da terra, praticamente desaparecem (Lima, 2020).

\subsection{O declínio do algodão no semiárido nordestino}

No auge do ciclo de produção do algodão no semiárido nordestino, até os anos 1970, a área cultivada chegou a ser superior a dois milhões e meio de hectares. Mesmo assim, nessa época, a cotonicultura nordestina já evidenciava sinais de esgotamento. Pois, de uma parte, as grandes propriedades de algodão eram extremamente desiguais e exploratórias, graças às relações de meia estabelecidas entre seus proprietários e os moradores e trabalhadores arrendatários (Almeida \& Parisius, 1995). Mas, ainda que desiguais, essas relações permitiram criar diversos postos de trabalho em que os trabalhadores se sentiam participantes e, de alguma forma, proprietários da produção (Andrade, 1973). E, de outra parte, o parcelamento das propriedades entre herdeiros gerou intensificação de uso da terra, com reflexos decrescentes sobre a produtividade.

Mas, foi no final da década de 1970 que o algodão do nordeste passou a perder espaço nos mercados, face ao somatório de um conjunto de fatores: baixa produtividade, serviço de assistência técnica bastante fragilizado e desmotivado, falta de acesso às linhas de financiamento, alto custo de transporte e logística, ausência de uma política para proteger os agricultores das oscilações de preços internacionais, cadeias locais frágeis, desorganizadas e baseadas em intermediários, com baixo valor agregado. Fato é que, segundo alguns autores, o modelo de cotonicultura até então adotado na região tornou-se obsoleto diante das novas dinâmicas da agroindústria algodoeira (Cartaxo et al., 2008). 
O mercado se voltou, então, para o consumo de produtos oriundos das propriedades e regiões que adotaram sistemas de produção baseados em pacotes tecnológicos convencionais, cuja oferta garantia maior regularidade e previsibilidade diante das oscilações da produção causadas pelas secas. As novas áreas de produção se expandiram, a despeito dos baixos níveis de sustentabilidade ambiental, tamanho o grau de contaminação das pessoas, do ar, do solo e dos rios com o uso intensivo de agrotóxicos (Haney et al., 2009).

Essa situação se agravou ainda mais na década de 1980 com os registros dos primeiros ataques do Bicudo do Algodoeiro (Anthonomus grandis) nos cultivos de algodão. O bicudo tornou-se, rapidamente, a principal praga desta cultura, determinando já em 1983 o início de uma "nova era" sem o algodão e de carência na região (Mattos, 2017). Fato é que a impossibilidade de seguir cultivando o algodão em regime de meia, agravada pela seca de 1980-83 e pela elevada concentração da terra, levou a uma situação generalizada de calamidade social, que impulsionou a um forte êxodo rural, principalmente de jovens rurais, na maioria dos estados do Nordeste (Mattos, 2017). Segundo o mesmo autor, a população rural tornou-se proporcionalmente mais idosa e descapitalizada, incapaz de gerar novos ciclos de cultivo para a recuperação da cotonicultura, o que desencadeou um novo ciclo vicioso de pauperização e insegurança alimentar na região.

Na década de 1990, todas as políticas de incentivo à produção e subsídios foram desmontadas em nome do aumento da competitividade interna. Exemplo disso foi a extinção do sistema brasileiro de assistência técnica e extensão rural. Ademais, a economia brasileira abriu-se para o mercado externo por meio de uma redução drástica das tarifas alfandegárias, que, associada a facilidades internas de financiamento das importações, foi responsável pela entrada de algodão no país. Parte desse algodão importado contava com subsídios em seus países de origem, o que lhe permitia chegar ao Brasil a preços mais baixos do que o produzido localmente, conquistando o mercado nacional da indústria têxtil (Cartaxo et al., 2008).

Diante desse cenário, a expansão da cotonicultura ocorreu em direção ao cerrado brasileiro, inclusive nordestino, fato que levou a Bahia a assumir o posto de maior estado produtor da região (Araújo Filho et al., 2013). Isso pode ser visto nos dados históricos de produção e área cultivada com algodão no Brasil que constam dos gráficos apresentados nas Figuras 1 e 2 (Conab, 2020).

Por fim, considerando o exposto acima, pode-se perceber que as causas que confluíram para o declínio da cotonicultura no semiárido nordestino foram muitas. O bicudo foi apenas uma delas e talvez a mais simbólica e marcante no imaginário popular.

Desde então, os "tempos do algodão" no semiárido foram definitivamente marcados como o antes e o depois da chegada do bicudo. E é nesse contexto que se pode compreender precisamente como o bicudo se tornou o vilão do desaparecimento do algodão comercial na região. Desde o encerramento do ciclo do algodão mocó em meados dos anos 1980, até então considerado como o "ouro branco do Nordeste", a região busca uma alternativa que o substitua como "cultura de renda". 


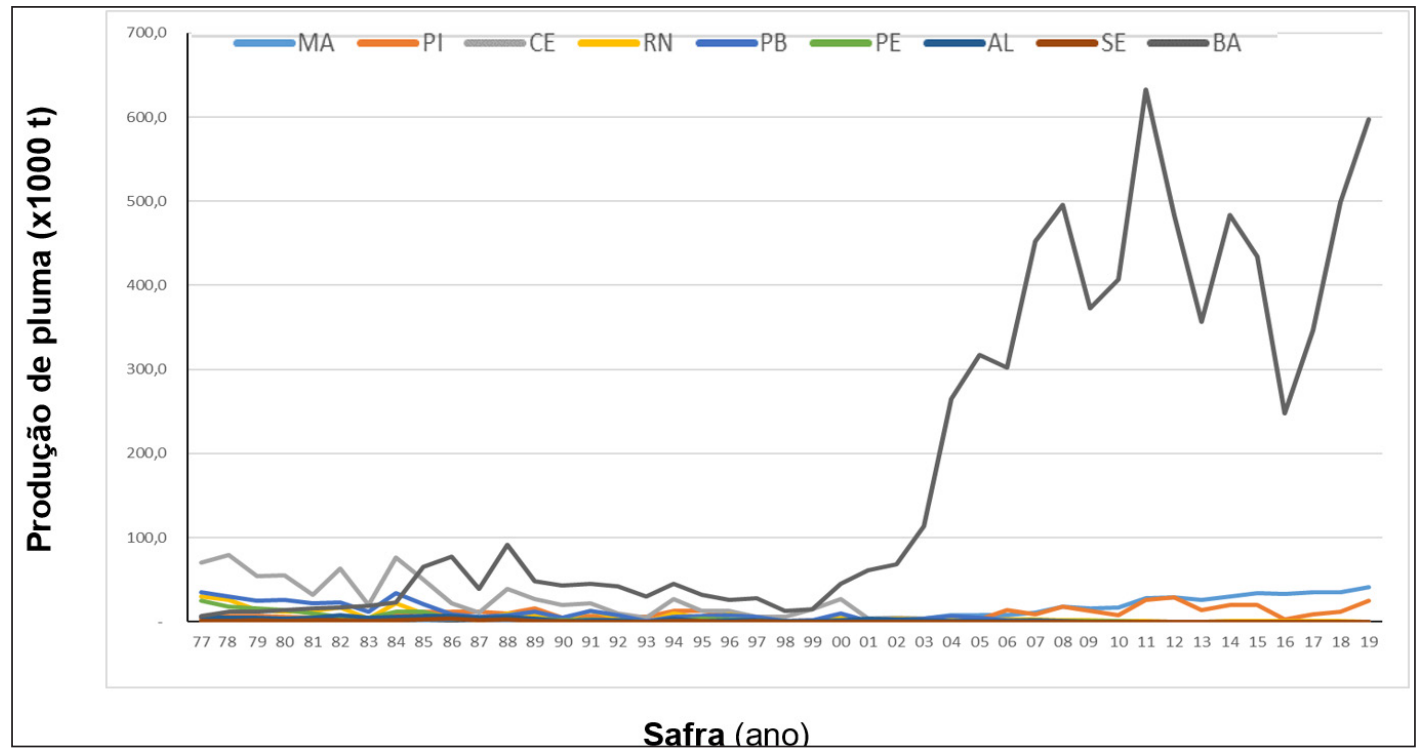

FIGURA 1 - Evolução histórica (safras de 1976 a 2019) da produção de pluma de algodão nos estados da região nordeste do Brasil (Conab, 2020).

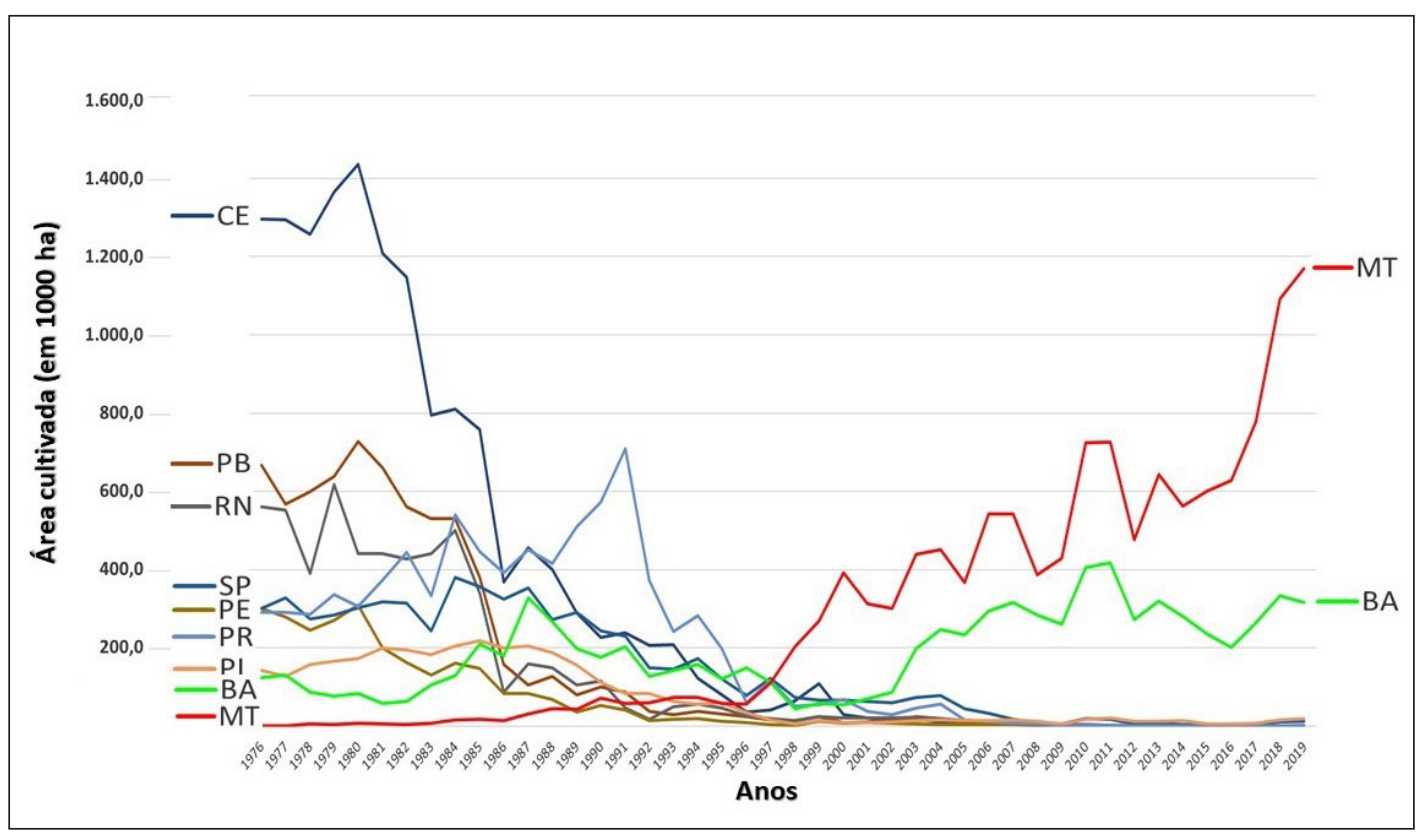

FIGURA 2 - Evolução histórica da área cultivada de algodão nos principais estados produtores (safras de 1976 a 2019) (Conab, 2020). 


\section{A retomada do cultivo de algodão no semiárido nordestino em bases agroecológicas}

A partir da década de 1980, concomitantemente ao declínio da produção do algodão no semiárido brasileiro, veio à tona a discussão sobre a questão ambiental, que passou a evidenciar mais claramente os impactos devastadores das opções tecnológicas dominantes baseadas na proposta ou modelo da revolução verde. Pois, como se sabe, esse modelo vem imprimido em nível mundial uma lógica perversa de se fazer agricultura via pacotes tecnológicos, cujos desdobramentos têm sido deletérios, principalmente para os sistemas de produção de agricultura camponesa familiar (Weid, 2013). Foi então que inúmeras iniciativas surgiram no mundo todo como um contraponto à revolução verde, cujos resultados se materializaram em um modo alternativo de se fazer agricultura. E no Brasil e no Nordeste isso não foi diferente, pois uma quantidade significativa de sistemas de produção foi identificada e sistematizada em todo território nacional, tão diversa quanto diverso foi o número de unidades produtivas envolvidas. Esses modelos alternativos forneceram as bases para aquilo que se convencionou chamar de agricultura de base agroecológica, que está fortemente baseada na eficiência da utilização do capital natural e nas relações tróficas entre agroecossistemas locais (Ogilvy, 2015). Tais iniciativas contaram com apoio crucial de organizações de cooperação internacional, que resultou na experimentação de tecnologias apropriadas e na difusão de inovações com vistas ao fortalecimento da agricultura camponesa familiar em diferentes territórios brasileiros.
No âmbito da sociedade civil, a melhor referência de desenvolvimento tecnológico para cotonicultura em bases agroecológicas foi desenvolvida no Estado do Ceará, sob a liderança do engenheiro agrônomo Pedro Jorge Lima, ligado à organização não governamental do Centro de Pesquisa e Assessoria (Esplar). Seu trabalho teve início em meados dos anos 1990, no município de Tauá-CE, e aos poucos foi sendo expandido para os municípios de Choró, Quixadá e Massapê, de sorte que, após uma década, em torno de duas centenas de agricultores e agricultoras familiares já estavam envolvidos na retomada do cultivo do algodão, que perfazia uma área total menor que 200 ha (Lima et al., 2005). Esse período inicial de lenta retomada do crescimento e expansão, tanto em área cultivada quanto em número de agricultores e agricultoras envolvidos/as, indica o grau de dificuldade enfrentado no processo experimental, pois várias foram as tentativas, bem ou mal-sucedidas, de revitalização do algodão mocó nos moldes dos sistemas tradicionais de cultivo de algodão no semiárido. Não obstante, essas experiências de tentativa e erro para a recuperação da cultura do algodão tiveram como objetivo central o enfrentamento do forte empobrecimento da agricultura familiar, que nunca conseguiu substituir o algodão como cultivo de renda. Já a inserção do algodão em arranjos mais sustentáveis e agroecológicos implicou a formulação de um plano sob vários outros aspectos, para além do produto em si, que incorporou, por exemplo, a qualidade do solo, a valorização da biodiversidade, a utilização mais sustentável dos recursos renováveis (como água e biomassa) e não renováveis (como nutrientes e combustíveis) (Lima, 2020).

Outro desafio foi desenvolver sistemas para diversificar a oferta de alimentos sadios e promover 
a segurança alimentar, sem, contudo, acarretar em uso rival de recursos naturais.

O trabalho pioneiro do Esplar continha também elementos de formação para desenvolvimento de uma consciência ecológica das famílias envolvidas. O processo social, portanto, era incorporado aos procedimentos de investigação empírica, como o software do componente tecnológico ${ }^{6}$. Dois tipos de organizações sociais de base local tiveram profundo envolvimento nesta iniciativa: a Associação de Desenvolvimento Educacional e Cultural (ADEC), que reunia agricultores e agricultoras do campo agroecológico em Tauá, e os Sindicatos de Trabalhadores(as) Rurais (STRs) dos municípios envolvidos(Lima et al., 2005).

Assim, o desenvolvimento tecnológico era integrado, em parte, por técnicas e produtos (har$d$ ware) e, de outra parte, por processos sociais (software), que se constituíram na chave para a concepção que se tem hoje dos consórcios agroecológicos com algodão.

Do ponto de vista do itinerário técnico, os arranjos dos consórcios estabelecidos nas iniciativas realizadas pelo Esplar no Ceará serviram de referencial para os cultivos de algodão até os dias atuais. A despeito das pequenas diferenças locais na sua composição, o algodão era consorciado basicamente com milho (Zea mays), feijão de corda (Vigna unguiculata), gergelim (Sesamum indicum) e guandu (Cajanus cajan), além de outras culturas com densidades de semeadura menores e variadas. Ademais, dessa diversidade de espécies alimentícias, os primeiros experimentos utilizaram na maior parte variedades de algodoeiro de pluma branca $7 \mathrm{MH}$, resultante do cruzamento entre as variedades mocó e herbáceo típico, ao passo que em uma pequena percentagem utilizou-se algodão BR200, marrom. Essa diversidade dos sistemas ampliou as alternativas produtivas, garantindo maior flexibilidade e resiliência econômica, ampliando a segurança alimentar, ao mesmo tempo que reduziu os riscos de perda nas safras (Lima et al., 2005).

\subsection{A convivência com o bicudo}

O principal aspecto a ser enfrentado no desenvolvimento dos sistemas de produção de base agroecológica de algodão foi e tem sido o enfrentamento e a convivência com a praga do bicudo. Se, como exposto anteriormente, o bicudo foi um dos fatores da decadência do algodão no semiárido brasileiro, também para a recuperação da cotonicultura em bases agroecológicas ele tem sido um dos principais entraves. O bicudo, apesar de ser uma espécie exógena, naturalizou-se no bioma Caatinga e tem dificultado o cultivo comercial do algodão. Parte disso se deve à maneira como transcorreu a derrocada dos sistemas tradicionais de produção do algodão em termos de manejo, uma vez que os cultivos foram simplesmente abandonados. E isso fez com que a recuperação da vegetação da caatinga, após o declínio da atividade, ocorresse com o "enriquecimento" da capoeira com a população de algodão mocó, que propiciou as condições ecológicas favoráveis à reprodução e à permanência do bicudo no bioma Caatinga, que passou a se alimentar das plantas de algodão mocó em meio às capoeiras abandonadas. Assim, quaisquer tentativas

${ }^{6}$ Considerando-se tecnologia como a composição de hardware e software (Practical Action, 2013). 
de cultivo de novos campos de algodão próximos a essas capoeiras abandonadas com presença do algodão mocó resultaram em elevados níveis de infestação, com danos bastante significativos à produção (Lima, 2020).

Os primeiros passos para o desenvolvimento de técnicas de convivência com o bicudo foram dados quando os pesquisadores deixaram de olhar para o inseto e voltaram-se para a ecologia dos cultivos e todos os seus componentes. Isso não foi uma tarefa fácil, dado o estigma criado no imaginário da população do semiárido sobre o bicudo.

E embora os princípios agroecológicos não preconizem a eliminação da população de insetos e dispensem o uso de agroquímicos sobre os cultivos, foi precisamente dos resultados de pesquisas sobre manejo químico de pragas, visando à erradicação do bicudo nos EUA, que surgiram as evidências em termos de manejo que passaram a orientar as práticas de convívio com o bicudo nos sistemas de base agroecológica no semiárido. Os estudos americanos revelaram que os custos adicionais com pesticidas não compensavam os níveis de danos evitados com o seu uso na cultura do algodoeiro, mesmo utilizando-se das mais eficazes formas de controle na época (King \& Powell, 1992).

Ademais, as principais pragas do algodoeiro passaram a desenvolver resistência aos inseticidas disponíveis. Isso tudo fez com que os diversos segmentos da cadeia produtiva do algodão, naquele país, passassem a trabalhar de forma institucionalmente integrada, valendo-se de tecnologias de manejo culturais e do estabelecimento de diapausas forçadas para dificultar a proliferação das pragas ${ }^{7}$ (Harris et al., 1996).

No entanto, os níveis de aplicação de inseticidas e o número de aplicações a cada safra tornaram-se de tal forma elevados que passaram a inviabilizar a cultura e diminuir a competitividade do algodão estadunidense (Haney et al., 2009). Isso, por um lado, criou um ambiente propício para que fossem adotadas ações coordenadas e que levassem à redução do volume de inseticidas na cultura do algodão. Por outro lado, foi levada a cabo uma série de pesquisas que, pouco a pouco, permitiram diminuir os gastos com aplicações de produtos crescentemente mais tóxicos, pela implantação de programas governamentais de monitoramento de populações de insetos (Harris et al., 1996).

Fato é que inúmeros programas bem-sucedidos de erradicação do bicudo foram criados em diversos estados nos EUA. Tais programas ainda contemplavam as aplicações de inseticidas sintéticos, mas também envolviam um amplo espectro de medidas, incluindo controle biológico, plantios coordenados e diapausas forçadas.

Esses sistemas coordenados de ação e planejamento de plantios foram trazidos ao Brasil pela experimentação acadêmica e pelos serviços de transferência de tecnologia, servindo de referência para se pensar processos sociais e ações coletivas para enfrentar o bicudo e evitar níveis elevados de danos. Esses procedimentos e articulações foram aos poucos incorporados aos itinerários técnicos do

\footnotetext{
${ }^{7}$ As diapausas são períodos de baixa atividade biológica, em que fatores externos ou fisiológicos impõem às populações uma estagnação no crescimento e na reprodução. No caso do controle do bicudo, elas são estabelecidas pela destruição dos restos vegetais da cultura, reduzindo a fonte de alimento e eliminando eventuais ovos e larvas restantes na cultura. As diapausas eram as técnicas predominantes no fim do século XIX e início do século XX, quando o bicudo cruzou a fronteira do México com os EUA (Haney et al., 2009).
} 
cultivo de algodão consorciado pelas organizações não governamentais (ONGs) na região semiárida (Blackburn, 2012; Lima, 2020). Criaram-se assim os arranjos institucionais necessários para consolidação do cultivo do algodão em consórcios agroecológicos.

As experiências da Esplar com algodão desde a década de 1990 no Ceará revelaram-se promissoras e de referência para que os arranjos institucionais ganhassem corpo desde então. Suas pesquisas empíricas despertaram, em 2005, o interesse de alguns pesquisadores da Embrapa Algodão ${ }^{8}$. Como resultado, criaram-se ambientes de colaboração para elucidar, sistematizar ${ }^{9}$ e tornar a experiência do Esplar uma referência para políticas públicas de crédito agrícola e assistência técnica (Lima, 2020).

Um elemento importante desse esforço foi o início das atividades do Projeto Dom Hélder Camara (PDHC) $)^{10}$, uma experiência piloto e inovadora de assistência técnica e extensão rural voltada para o semiárido brasileiro. A estratégia do PDHC passava pelo estímulo à constituição de parcerias entre a sociedade civil e setores da pesquisa e das cadeias produtivas, organizadas em bases territoriais abrangidas pela ação do projeto $^{11}$. Foi então que essas articulações se ampliaram para estabelecer os primeiros contatos com as empresas dos mercados da moda e que viriam a se tornar as compradoras regulares do algodão agroecológico do Semiárido.
O PDHC deu um impulso institucional e financeiro crucial para o desenvolvimento e a expansão das estratégias coletivas e territoriais, garantindo a assistência técnica de base agroecológica por meio de parcerias com as entidades da sociedade civil, de forma continuada e permanente (Sidersky et al., 2010). Esses arranjos deram suporte a complexos sistemas de formação em termos de experimentação, acompanhamento técnico e fortalecimento da gestão social às famílias que aderiram às ações de revitalização do cultivo do algodão consorciado com espécies alimentares em sistemas agroecológicos. Da mesma forma, articulações foram construídas territorialmente visando à viabilização de recursos para aquisição de máquinas e equipamentos com vistas à consolidação dos arranjos produtivos nos territórios de abrangência do PDHC.

As articulações do PDHC com ONGs, movimentos sociais, entidades de pesquisa, setor privado e comunidades locais no semiárido resultaram em ações coordenadas para viabilizar a produção agrícola de base agroecológica em arranjos institucionais e processos sociais semelhantes aos que foram construídos por ocasião da erradicação do bicudo em certos estados norte-americanos. Contudo, os desenhos dos sistemas produtivos desenvolvidos no semiárido brasileiro seguiram um caminho diferente, em que sua concepção obedeceu a princípios agroecológicos.

\footnotetext{
${ }^{8}$ Pela dedicação e interesse destacam-se os pesquisadores Melchior Naelson Batista da Silva e Fabio Aquino de Albuquerque.

${ }^{9}$ A Embrapa usa o termo "validado" quando, após algum nível de investigação, uma experiência empírica, ainda que com razoável grau de sucesso e aceitação social, passa a ter "comprovação científica".

${ }^{10} \mathrm{O}$ PDHC foi fruto de um acordo de empréstimo entre o Fundo Internacional de Desenvolvimento Agrícola (FIDA) e o governo brasileiro. Apesar de ser um projeto do governo federal, era voltado exclusivamente para o semiárido brasileiro e desenvolvido em oito territórios de seis estados brasileiros.

${ }^{11}$ Foram também estabelecidas parcerias com: Secretaria de Desenvolvimento Agrário (SDA) e EMATERCE, ligadas ao Governo do Estado do Ceará; Empresa de Pesquisa Agropecuária do Rio Grande do Norte (EMPARN); outras unidades da EMBRAPA (Cenargen e Caprinos e Ovinos); Universidade Federal do Ceará (UFC) e Universidade Federal de Campina Grande (UFCG).
} 
Isso implicou, por exemplo, a adoção do agroecossistema como unidade de análise, o que resultou em desafios consideráveis do ponto de vista da orientação técnica, na medida em que incorporou aos procedimentos técnicos a visão sistêmica. Para se ter uma ideia, os sistemas de cultivo dos agricultores também eram utilizados como referência para práticas de experimentação, cujo objetivo era compreender as racionalidades e estratégias dos grupos de agricultores, assessorados por uma equipe em permanente treinamento. Isso permitiu ao pessoal da equipe técnica, agricultores e agricultoras novas perspectivas de organização do conhecimento, com superação do enfoque metodológico centrado em tecnologias pontuais, passando a abordá-las a partir de uma visão sistêmica, ou seja, pelas suas funções como mediadoras de relações ecológicas e socioeconômicas nos agroecossistemas (Blackburn, 2012).

Atualmente, as iniciativas envolvendo o cultivo de algodão na forma de consórcios agroecológicos vêm sendo desenvolvidas com apoio de entidades de cooperação internacional e de projetos sociais ${ }^{12}$, sob a liderança e responsabilidade de algumas das organizações que compunham a base de assessoria técnica do PDHC. Dentre elas pode-se citar: Diaconia (equipes em Recife, Pajeú/PE e Umarizal/RN), Caatinga/PE, Esplar/CE, Chapada/ PE, Instituto Palmas/AL, CDJBC/SE e Cáritas/PI, AS-PTA/PB, Arribaçã/PB, Universidade Federal de Sergipe e Embrapa Algodão. Sua organização conta localmente com Organismos Participativos de Averiguação da Conformidade Orgânica (OPAC), além das parcerias com as compradoras de algodão que, por sua importância, cumprem um papel estratégico nesses arranjos.

\subsection{Desenho do modelo tecnológico do} sistema de cultivo (hardware tecnológico) e do processo social (software social)

\section{i) O hardware tecnológico}

Os agricultores familiares, pela sua natureza e tradição, constituíram-se na base social que deu suporte às novas experiências com o algodão no semiárido, ao oferecerem as bases físicas para a produção e fornecerem a força de trabalho para o desenvolvimento dos sistemas de cultivo em consórcio agroecológico, advindo de processos participativos de construção do conhecimento. $\mathrm{O}$ algodão tem sido experimentalmente cultivado em consórcios agroecológicos em centenas de propriedades, em áreas que giram em torno de 1,0 ha, formando uma rede de projetos biodiversos cujos resultados têm alimentado um banco de dados que serve de base para o aprimoramento técnico dos cultivos. Após alguns ciclos de cultivo, que contaram também com a colaboração da pesquisa e assistência técnica, notadamente da EMBRAPA e do PDHC, foi possível estabelecer os pilares técnicos do sistema que vem sendo adotado (Lima, 2020):

Cuidados com o solo: plantio em nível e em faixas para controle da erosão; adubação orgânica e biofertilizante;

Uso eventual de produtos naturais: como caldas de nim e urina de vaca;

Monitoramento permanente dos cultivos: para detecção e catação de insetos e botões florais caídos do algodoeiro para prevenção de pragas, principalmente o bicudo e a lagarta rosada (Pectinophora gossypiella). O bicudo tem sua maior incidência após a emissão dos primeiros botões florais pelas

${ }^{12}$ Laudes Foudation (ex-Instituto C\&A), Porticus e FIDA. 
plantas de algodão e é, portanto, nessa fase que o monitoramento se intensifica. Caso seja identificada sua presença, é realizada a catação e destruição dos botões florais caídos;

Plantio coordenado: em grupo ou comunidade, com o objetivo de escapar da incidência do bicudo sem nível de dano. Para haver melhor aproveitamento das variadas e escassas chuvas do semiárido, todos os agricultores e agricultoras devem fazer monitoramento também do comportamento das chuvas; Vazio sanitário: manejo dos restos culturais com retirada de todo o material vegetal da área de plantio; Plantio em faixas em que o algodão não ocupe mais do que $50 \%$ da área de cultivo: assim é possível estabelecer um plano de rotação dentro da mesma área, evitando-se e/ou reduzindo-se o impacto sobre a vegetação nativa. O plantio em faixas é também responsável por formar barreiras físicas para evitar a proliferação dos insetos mais danosos ao algodão.

O sistema dos consórcios consiste basicamente no arranjo de cultivos distribuídos em faixas, alternando-se o algodão com milho, feijão, gergelim e amendoim. Assim, se preservam níveis mínimos de segurança alimentar das famílias e dos animais. $\mathrm{O}$ gergelim, além do interesse comercial, tem a função de ajudar a prevenir o ataque de formigas cortadeiras (Atta sp.). Além disso, constituem-se em nichos ecológicos para facilitar a proliferação de insetos que possam agir como predadores das pragas, os chamados inimigos naturais (Lima et al., 2005).

A implantação dos cultivos de algodão, gergelim e amendoim é feita com sementes certificadas de variedades melhoradas $^{13}$, ao passo que nos cultivos de milho e de feijão utilizam-se sementes crioulas. Os cultivos subsequentes são realizados geralmente com aproveitamento das sementes produzidas localmente na safra anterior. As faixas de milho e de algodão são intermediadas por faixas de feijão, amendoim ou gergelim para evitar o sombreamento do algodão e melhorar o aproveitamento de nutrientes no solo em função da fixação biológica do nitrogênio ou do hábito de crescimento destas espécies. Além disso, nas entrelinhas do algodão não há cultivo de outras espécies vegetais. Essas espécies, quando presentes, são dispostas nas entrelinhas do milho. Essas outras espécies são, comumente, melancia, fava, guandu e sorgo, e também se destinam ao consumo da família ou à alimentação animal. O preparo do solo, em geral, é mecanizado ou realizado com tração animal. Mas, por falta de condições materiais, muitas famílias ainda realizam a sistematização do terreno para plantio de forma manual, o que implica um dispêndio de mão de obra excessivo. O espaçamento nas faixas de algodão, em geral, gira em torno de $40 \mathrm{~cm}$ na linha e 1,0 m nas entrelinhas de plantio. As sementes de algodão são $\operatorname{lintadas}^{14}$, o que geralmente resulta na distribuição irregular de sementes e, consequentemente, na alta densidade de plântulas por berço de plantio. Por isso, recomenda-se a realização de desbaste aos 25 dias após a semeadura, deixando-se duas plântulas mais vigorosas de algodão por berço de plantio (Albuquerque et al., 2011).

ii) O software social

Além do desenho e das recomendações para a condução do consórcio, passa a operar o software

\footnotetext{
${ }^{13}$ Algodão - BRS Aroreira, que tem elevado teor de óleo; gergelim - BRS Seda; e amendoim BR-1.

${ }^{14}$ Semente lintada: designa de "linter", que é o nome atribuído aos restos de fibra que ainda se mantêm aderidos à semente.
} 
social, ou seja, um esforço coletivo entre os agricultores e técnicos no sentido de estabelecer processos sociais que impliquem cultivos coordenados, sincronizando as datas de plantio de todas as unidades produtivas de tal maneira que os campos de algodão de uma determinada zona de controle estejam sempre no mesmo estágio de desenvolvimento. Isso implica necessariamente monitoramento da precipitação pluviométrica, que deve ser realizada por todas as famílias agricultoras. Também é necessário que as sementes estejam disponíveis para todos os campos de cultivo na época correta (Albuquerque et al., 2011).

Todo esse processo social, ou seja, software social de tecnologia, está amparado em sistemas de registro, com auxílio de cadernos de campo, grupos de comunicação com envios de mensagens instantâneas via celular e consolidação das informações em um banco de dados. Além disso, as famílias participantes do projeto encontram-se mensalmente, contam com a orientação de técnicos experimentadores locais e acompanhamento das assessorias técnicas das ONGs locais. A gestão dos bancos de dados é realizada pelas organizações dos agricultores e agricultoras, em cujas informações constam área cultivada, estimativa de produção, dados pluviométricos, práticas de cultivo adotadas, características de relevo, ocorrência e manejo de pragas, entre outras (Blackburn, 2012).

Mas, todo esse esforço tem levado a um dispêndio de mão de obra em níveis elevados, o que pode estar impedindo a ampliação das áreas cultivadas. Ademais, vale salientar que esse inten- so processo social com demandas por assistência técnica cada vez mais sofisticada colocariam em cheque a viabilidade econômica do conjunto da experiência se as bases de negócio ainda fossem nos moldes do mercado convencional. Ou seja, toda essa tecnologia seria inviável diante da desestruturação dos circuitos tradicionais de comercialização do algodão, pois os preços praticados não justificariam todo esse esforço e investimento.

\subsection{O descaroçamento em pequena escala}

O descaroçamento é um dos componentes centrais da estratégia de desenvolvimento do algodão em consórcios agroecológicos. É responsável pelo primeiro estágio da agregação de valor na cadeia produtiva. Se, por um lado, a pluma, ao invés da rama $^{15}$, remunera melhor a quem produz, por outro permite a quem descaroça se apropriar dos caroços como subproduto.

O caroço do algodão desempenha três funções de base agroecológica importantes: (i) constitui estoque de sementes para reprodução dos consórcios nos anos subsequentes; (ii) é uma importante fonte proteica para alimentação animal; e (iii) possui elevados teores de óleo. O domínio sobre o descaroçamento também influi na relação com intermediários, que tradicionalmente são responsáveis pela compra de algodão em rama para renegociá-lo em usinas de descaroçamento. Nessa negociação, os preços praticados, ainda no meio rural, tendem a ser pressionados para baixo, para aquém dos custos

\footnotetext{
${ }^{15}$ Rama é a designação para o produto colhido no campo, que é composto de 35 a $45 \%$ de pluma, 55 a $60 \%$ de caroço e 3 a $9 \%$ de palha de casca e impurezas, dependendo da composição (Santos et al., 2009).
} 
de transporte, armazenamento e remuneração dos serviços de quem o faz ${ }^{16}$.

Essa preocupação com o domínio do processo de descaroçamento já havia desde os anos 1980, quando das primeiras experiências no Ceará com desenvolvimento dos sistemas de base agroecológica do algodão pela Esplar. Porém, o alto custo associado a pequenos volumes de produção inviabilizava a aquisição de equipamentos de descaroçamento exclusivamente para algodão em consórcio agroecológico. Dessa forma, a regra era terceirizar o processo de beneficiamento às algodoeiras que processavam todo tipo de algodão, tanto convencional quanto agroecológico. Ademais, a decadência do algodão na região fez com que muitas dessas unidades fechassem as portas e se desfizessem de seu maquinário. Em muitos casos, essas máquinas depreciaram ou deterioraram por falta de manutenção ou, ainda, se tornaram obsoletas, não dispondo mais de peças de reposição (Lima, 2020).

Isso se agravou ainda mais com a modernização recente do setor e crescimento do agronegócio do algodão, que atraiu o setor de descaroçamento para as proximidades da fronteira agrícola do algodão convencional nos cerrados do Piauí, Bahia e Maranhão (Araújo Filho et al., 2013).

Ademais, a agregação de valor monetário à fibra do algodão exige qualidade agroecológica e, portanto, não admite contaminação com o algodão convencional. Isso tem criado um impasse para o processo de beneficiamento, pois, além de ter que superar a depreciação do produto imposta pelo atravessador, o descaroçamento deve ser realizado em uma algodoeira específica, de modo a eliminar a contaminação da fibra.

Mas, a partir dos anos 1990 começaram a surgir as primeiras iniciativas de desenvolvimento de modelos de algodoeiras adaptadas ao descaroçamento e à prensagem em pequena escala por metalúrgicas, principalmente da Paraíba e de Pernambuco. Com isso, o beneficiamento do algodão começou a se realizar mais próximo das propriedades rurais onde é cultivado. Do ponto de vista acadêmico, pesquisas realizadas com esses modelos mais compatíveis indicaram que o descaroçamento não afeta a germinação das sementes, o que garante a disponibilidade das sementes para o plantio nos anos subsequentes (Jerônimo et al., 2014). Assim, protótipos de 10 serras experimentais (sem prensa) foram desenvolvidos em Pernambuco, ainda no início dos anos $1990^{17}$. Mas, foram os primeiros modelos de 50 serras construídos em Juarez Távora, no Estado da Paraíba, que acabaram servindo de referencial para o descaroçamento em pequena escala. Fato é que os modelos evoluíram até que se chegasse às versões atuais de 20 a 25 serras. $\mathrm{Na}$ prática, a eficiência do descaroçamento em unidades descentralizadas de 25 serras tem se demonstrado

\footnotetext{
${ }^{16}$ Informações colhidas em campo junto aos agricultores acompanhados pela ONG Diaconia, por meio do trabalho de assistência técnica ao Projeto Algodão em Consórcios Agroecológicos (Diaconia, 2019).

${ }^{17}$ Foram construídas dez unidades de um modelo de descaroçadora de dez serras por Roberto Wanderlei, um empresário autodidata e inovador de Recife, cuja fábrica não era especializada neste tipo de equipamento. Com apoio da cooperação internacional, um modelo desses chegou a ser experimentado no Ceará pelo Esplar. As outras unidades foram testadas por agricultores no município de Surubim, no Estado de Pernambuco, com apoio do Governo do Estado de PE. No entanto, o baixo rendimento e a prensagem manual levaram a um desinteresse pelas comunidades. Sem apoio ao seu desenvolvimento tecnológico, a iniciativa foi descontinuada. Após o seu falecimento, seus herdeiros fecharam a fábrica e a iniciativa se perdeu da história (Lima, 2020).
} 
adequada aos objetivos pretendidos de se produzir a pluma orgânica/agroecológica certificada, de modo a comercializá-la nas cadeias do comércio justo e orgânico (Lima, 2020).

\subsection{Mercados da moda e a demanda por matérias-primas mais sustentáveis}

Nos últimos anos, o conceito de consumo consciente tem ganhado força na sociedade, que tem buscado produtos agrícolas livres de pesticidas e contaminantes.

Até o final da década de 1980, as principais críticas aos mercados referiam-se às tecnologias de produção. Isso se tornou evidente no caso das cadeias da indústria têxtil e cotonicultura em função dos grandes volumes de produtos químicos e de alta toxicidade aplicados às lavouras de algodão convencional (Haney et al., 2009).

Mas, foi com a publicação em 1987 do Relatório Brundtland ${ }^{18}$ que a questão ambiental se tornou mais ampla ao tratar da necessidade de se estabelecer o desenvolvimento sustentável. Nessa mesma direção, a ECO- $92^{19}$ desempenhou um papel decisivo para a mudança do pensamento político ambiental, em que padrões de consumo e produção passaram a ser vistos como esferas a serem reformuladas. Essa percepção ganhou força na sociedade de tal sorte que os impactos ambientais provocados pela ação humana levaram a uma preocupação sobre os padrões de vida e níveis de consumo, sobretudo nos países mais ricos. E como resultado dessa nova consciência ambiental proliferaram ONGs e grupos ativistas, que passaram a denunciar empresas e a exigir transparência nas cadeias têxteis de responsabilidade das marcas de moda. Esses grupos, baseados em relatórios e investigações científicas relacionadas principalmente à agricultura, ao uso de agrotóxicos e seus impactos, passaram a denunciar a insustentabilidade ambiental e social do sistema da moda. Exemplo disso são as ações lideradas pelas ONGs Clean Clothes, Oxfam, Greenpeace, WWF, Organic for Exchangin, The Nature, Conservancy e Forum For The Future, que resultaram na publicação de relatórios e artigos denunciando os impactos das lavouras de algodão e da produção de roupas sobre o meio ambiente (Berlim, 2016).

Ocorre que a dimensão humana da crítica ecológica também revelou a questão social subjacente às cadeias têxteis globais, aproximando questões ambientais das questões sociais. Fato é que a crítica aos padrões de consumo ganhou força na associação da crítica social (ética) com a crítica aos costumes (estética), reunindo setores que buscavam, respectivamente, modificar ou modernizar os sistemas econômicos e de produção na economia capitalista (Boltanski \& Chiapello, 2009). Daí porque há, cada vez mais, a preocupação com as condições em que as mercadorias têm sido produzidas, valorizando condições mais justas tanto ambiental quanto socialmente.

E respondendo a essa tendência, a indústria da moda, em seus diferentes segmentos, tem tido

\footnotetext{
${ }^{18}$ Conhecido como Relatório Brundtland, o documento intitulado Nosso Futuro Comum (Our Common Future) foi publicado em 1987. A Comissão Mundial sobre o Meio Ambiente e o Desenvolvimento estabeleceu a crítica do modelo de desenvolvimento vigente, ressaltando os riscos do uso excessivo dos recursos naturais sem considerar a capacidade de suporte dos ecossistemas e apontando a incompatibilidade entre desenvolvimento sustentável e os padrões de produção e consumo vigentes.

${ }^{19}$ Conferência das Nações Unidas para o Meio Ambiente (PNUMA), realizada no Rio de Janeiro em 1992.
} 
cada vez mais interesse em adquirir produtos que possam atender a essa demanda. No entanto, no caso do algodão, há um enorme déficit de produção diante de um consumo crescente, ou seja, a indústria de moda passou a ter um grande "apetite" por algodão orgânico. Mesmo empresas historicamente pouco preocupadas com questões ambientais têm desenvolvido interesse pelos mercados orgânicos, notadamente de algodão, visando reposicionar suas marcas no mercado (Berlim, 2016).

As primeiras relações comerciais entre produtores e compradores dos mercados de algodão orgânico foram experimentadas em 1993 e envolveram entidades ambientalistas de âmbitos nacional e internacional ${ }^{20}$. Mas foi a partir da atuação do Projeto Dom Hélder Câmara que os contatos comerciais ganharam mais solidez, ao se estabelecer um modelo de assistência técnica para o semiárido. Ao menos três grupos ligados ao mercado de moda, mas com empreendimentos organizativos distintos, têm atuado com força na dinamização da jovem cadeia de produção do algodão de base agroecológica: Vert Shoes $^{21}$; Organic Cotton Colours e a Justa Trama, conforme descrição a seguir:

(i) Vert Shoes é uma fabricante do setor de calçados de origem francesa, mas que transferiu sua unidade de fabricação para o Brasil. Visa desenvolver produtos $100 \%$ derivados de ações sustentáveis e que promovam justiça e respeito a povos e comunidades tradicionais;

(ii) Organic Cotton Colours é uma entidade de corte empresarial da Catalunha, mas que promove uma rede internacional de comercialização de produtos derivados de algodão orgânico colorido (finais ou intermediários). Desenvolveu um selo próprio de certificação (OCCGuarantee $\AA$ ), mas também adquire matéria-prima de terceiros com certificação reconhecida;

(iii) Justa Trama é um empreendimento associativo brasileiro derivado de iniciativas nascidas no movimento da economia solidária. Tem menor penetração no semiárido brasileiro do que em outros biomas, como Cerrado e Amazônia. Representa uma holding de cooperativas e outros grupos menores que atuam nos diferentes elos da cadeia, seja da fiação, seja da confecção.

Apesar de estas empresas terem perfis e origens diferentes, com maior proximidade do comércio justo e da economia solidária ou com o mercado orgânico, na prática, hoje, todas elas possuem preocupações relacionadas tanto às questões ambientais quanto sociais.

Outro aspecto importante é que, independentemente da sua natureza jurídica (empresa autônoma, rede empresarial ou cooperativa de empreendimentos) do ponto de vista da relação comercial, as famílias produtoras não percebem a diferença entre elas. Esses empreendimentos têm estabelecido contratos de compra com os grupos de produtores de algodão no semiárido brasileiro em ao menos sete estados do nordeste, praticando preços justos e bem atrativos. Duas condições fundamentais têm colaborado para isso: i) o algodão é certificado e ii) o produto

\footnotetext{
${ }^{20}$ A Associação dos Agricultores Orgânicos de São Paulo (AAO) chegou a intermediar as relações entre agricultores ligados à Esplar com o Greenpeace, interessado em usar camisetas de algodão orgânico em suas campanhas. Essa relação só durou dois anos e não persistiu (Lima, 2020).

${ }^{21}$ Vert-shoes (www.vert-shoes.com.br) é o nome comercial no Brasil da Veja Store (www.veja-store.com), de origem francesa.
} 
comercializado é o fardo de pluma de algodão, já descaroçado e prensado (Diaconia, 2019).

Esse boom do mercado do algodão orgânico fez com que a demanda crescesse muito além da oferta, realinhando os preços praticados para até o dobro dos preços pagos na pluma de algodão convencional (Araújo Filho et al., 2013).

As mudanças no mercado de moda atraíram não só compradoras em potencial, mas também as fundações de empresas, ou seus departamentos de responsabilidade social. No caso específico do semiárido brasileiro, esse movimento tem sido representado pelo Instituto $C \& \mathrm{~A}^{22}$, que passou a desenvolver um programa de "matérias-primas sustentáveis", cuja cotonicultura é um dos focos principais. A parceria com o Instituto C\&A retomou parte da assessoria técnica antes fornecida pelo PDHC, que se desarticulou a partir de 2015 (Diaconia, 2019).

\subsection{A certificação participativa}

As mudanças no mercado de moda discutidas anteriormente abriram inúmeras oportunidades para que a agricultura familiar no semiárido pudesse nele se inserir, oferecendo fibra de algodão de base agroecológica e gerando paralelamente ganhos ambientais.

Para tanto, as empresas compradoras de algodão exigem certificação, o que, por sua vez, sempre foi um entrave, dado que o custo das auditorias para obtenção dos selos orgânicos tornava a certificação inacessível para a maior parte do público de agricultores que se enquadra no âmbito da agricultura familiar, que predomina no semiárido. A saída, nesse caso, foi o desenvolvimento de procedimentos para a obtenção do "Selo Orgânico Brasil" em processos participativos. Isso foi fruto do protagonismo das ONGs, notadamente da Rede Ecovida, que nos anos 1990 estabeleceu as bases conceituais para aquilo que se convencionou chamar de certificação participativa, mas que foi batizada orginalmente de "Certificação Participativa em Rede" (CPR). A própria Rede Ecovida acabou se tornando em 1999 uma entidade de certificação, sob a liderança de agricultores e agricultoras. E foi essa ideia original que norteou a concepção da lei que regulamentou os Sistemas Participativos de Garantia (SPG), que resguardaram os consumidores sem onerar as famílias agricultoras, além de permitir a elas o relacionamento com mercados orgânicos e o comércio justo (Costa, 2005).

Contudo, foi somente em 2007 que se criaram os mecanismos de regulamentação dos sistemas participativos de garantia, por intermédio dos Organismos de Averiguação da Conformidade Orgânica $(\mathrm{OPAC})^{23}$. Desde então, foram criados diversos OPACs pelo país. Até o presente momento, as experiências de cultivo de algodão em consórcios agroecológicos no Semiárido Brasileiro ${ }^{24}$ mantêm relação com os seguintes OPACs:

\footnotetext{
${ }^{22}$ A partir de janeiro de 2020 o Instituto C\&A passou a se chamar Laudes Foundation.

${ }^{23}$ Decreto $n^{\circ} 6.323$, de 27 de dezembro de 2007, que regulamenta a Lei $n^{\circ} 10.831$, de 23 de dezembro de 2003, que dispõe sobre a agricultura orgânica e dá outras providências (disponível em: http://www.planalto.gov.br/ccivil_03/_Ato2007-2010/2007/Decreto/D6323.htm).

${ }^{24}$ Além dessas experiências, há ainda o caso da ADEC - Associação para o Desenvolvimento Educacional e Cultural do Município de Tauá/ $\mathrm{CE}$ - que, apesar de ser vinculada à agricultura familiar, utiliza certificação de terceira parte com o Instituto Biodinâmico de Desenvolvimento (IBD) (Diaconia, 2019).
} 
APASPI - Associação dos Produtores Agroecológicos do Semiárido Piauiense - São Raimundo Nonato/PI;

ACEPA - Associação de Certificação Participativa Agroecológica - Quixeramobim/CE;

ACEPI - Associação Agroecológica de Certificação Participativa dos Inhamuns/Crateús - Crateús/CE; ECOARARIPE - Associação dos Agricultores e Agricultoras Agroecológicos do Araripe - Ouricuri/PE;

ACOPASA - Associação de Certificação Orgânica Participativa do Sertão do Apodi - Apodi/RN;

RBA - Rede Borborema de Agroecologia - Assentamento Margarida Alves I - Juarez Távora e Itabaiana/PB;

ASAP - Associação Agroecológica do Pajeú -Afogados da Ingazeira/PE;

ACEPAC - Associação Agroecológica de Certificação Participativa do Cariri Paraibano-Monteiro/PB.

Outras três organizações estão em vias de formalização de registro junto ao Ministério de Agricultura, Abastecimento e Pecuária (MAPA) e pretendem atuar na certificação dos consórcios agroecológicos com algodão nos territórios semiáridos do Alto Sertão de Alagoas, Alto Sertão de Sergipe e Agreste da Paraíba. Do ponto de vista dos processos sociais, elas já estão em funcionamento e estabeleceram contratos de fornecimento com a empresa Vert Shoes (Diaconia, 2019).

E, para além da previsão legal e exigência formal para a certificação, o que se verifica na prática é que os OPACs são de fato uma tecnologia social imaterial (software) associada às demais técnicas, insumos e procedimentos adotados para o desenvolvimento dos sistemas de produção de base agroecológica. Tal qual uma tecnologia social, o OPAC exige grande mobilização das pessoas envolvidas, desde a ação individual em cada unidade de produção até a gestão comunitária e territorial da certificação. Fato é que os OPACs tornaram-se um componente essencial para a produção de algodão no semiárido, de modo a vencer o desafio da certificação orgânica e lograr o acesso ao mercado de moda.

\section{Perspectivas do algodão em consórcios agroecológicos para a agricultura familiar}

\subsection{Análise econômica preliminar e relação com o semiárido}

As primeiras avaliações realizadas sobre os sistemas de produção do algodão em consórcios agroecológicos foram realizadas pela agência Etene, vinculada ao Banco do Nordeste, BNB (Araújo Filho et al., 2013). Nesse exercício foram comparados cinco modelos, cruzando o perfil da agricultura (agricultura familiar e agricultura patronal do agronegócio) com o sistema de produção (sistemas agroecológicos e cultivos convencionais). A comparação teve por objetivo lançar luz sobre a viabilidade dos sistemas agroecológicos no contexto da atual cotonicultura nordestina do semiárido, "sob ótica da competitividade" (Tabela 1).

As relações benefício-custo dos sistemas agroecológicos chegaram próximas a 1,0 para $o$ algodão colorido e superaram esse valor, chegando a quase 1,3, para o algodão branco, ao passo que os sistemas convencionais se situaram bem aquém desses valores. Dos cultivos convencionais, o mais próximo de 1 foi o algodão branco irrigado, cultivado no âmbito da agricultura familiar, com valor pouco acima de 0,4 . 
TABELA 1 - Resultados comparativos entre diferentes sistemas de cultivo de algodão no Nordeste

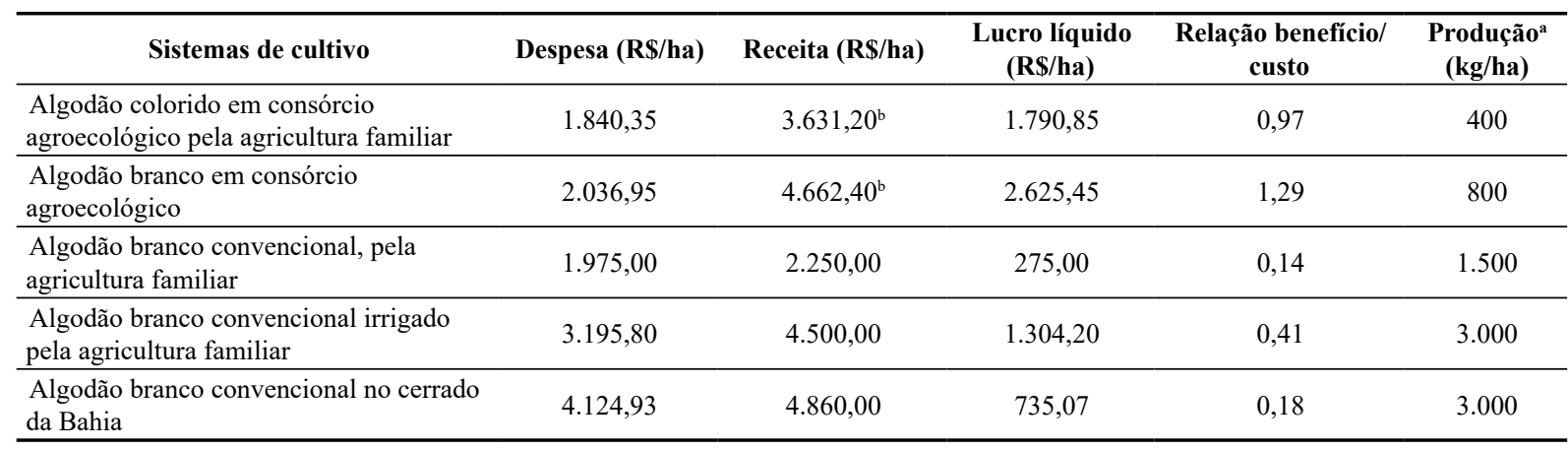

FONTE: Araújo Filho et al. (2013).

(a) Produção de pluma + caroço. No sistema convencional o algodão foi cultivado solteiro ou em monocultivo e no consórcio foi cultivado em policultivo. Nos consórcios agroecológicos o algodão ocupou no máximo $50 \%$ da área total cultivada.

(b) Receita auferida considerando todos os produtos cultivados no consórcio.

Apesar da menor produção de algodão por área cultivada nos sistemas agroecológicos, os retornos mais elevados foram obtidos pela combinação da diversificação dos produtos e preços diferenciados. Nesse sentido, as receitas nos consórcios agroecológicos foram obtidas não só pelo algodão, e o gergelim se mostrou tão promissor quanto o algodão na composição da renda do sistema. Além disso, o algodão agroecológico, uma vez certificado, atingiu preços duas vezes maiores que o algodão convencional, que compensaram a menor produção por área plantada.

Por meio dos resultados expostos na Tabela 1 é possível observar que os custos de produção dos sistemas agroquímicos são elevados e indicam grandes necessidades de insumos para se produzir algodão no cerrado, revelando, portanto, que as condições favoráveis são, na verdade, decorrentes de grandes investimentos em tecnologia, que arti- ficializam sobremaneira os cultivos. Dessa forma, tal qual foi verificado em pesquisas desenvolvidas nos EUA, os elevados custos de produção tendem a anular os ganhos potenciais (Haney et al., 2009).

O que se percebe é que o sistema de produção do algodão em consórcios agroecológicos mostrou-se bastante promissor para expansão no semiárido, com claros benefícios ao meio ambiente, por ser cultivado em sequeiro e contar com medidas protetivas ao solo.

\subsection{Potencial de expansão do algodão em consórcios agroecológicos diante dos mercados globais}

Segundo o último relatório da organização Textile Exchange $(2019)^{25}$, existem atualmente cerca de 183 mil agricultores cultivando algodão orgânico no mundo. Apenas 19 países participam desse

\footnotetext{
${ }^{25}$ Disponível em www.textileexchange.org
} 
mercado, sendo que em sete desses encontra-se $98 \%$ de todo o algodão orgânico produzido mundialmente. A produção total de algodão orgânico em 2018 totalizou 180.871 toneladas, colhidas em uma área total de aproximadamente 356.131 ha. Isso corresponde a apenas $0,7 \%$ de todo o algodão produzido no mundo.

A participação do Brasil nesse mercado é modesta. $\mathrm{O}$ algodão orgânico brasileiro ${ }^{26}$ teve um crescimento da área plantada no ano de 2019 (Diaconia, 2019), recuperando-se das sucessivas reduções registradas entre 2015 e 2018. Ainda assim, os dados da produção da safra 2018-19 permitem inferir que o volume de algodão orgânico brasileiro seguirá abaixo de 100 toneladas $^{27}$. Isso corresponde a um percentual entre 0,02 a $0,04 \%$ de todo o algodão orgânico produzido no mundo. É importante considerar também que o contexto da região semiárida impõe um grau de incerteza maior que outras regiões agrícolas do país. É, portanto, incerto tecer cenários de crescimento futuro, já que é daí que a maior parte da produção orgânica brasileira provém.

A tímida expressão do Brasil no mercado internacional do algodão orgânico também é reflexo do impacto negativo sofrido pelo setor em decorrência da reestruturação do PDHC, que ao rever suas as prioridades e forma de atuar, acabou por deixar de assessorar as experiências dos consórcios agroecológicos com algodão na região semiárida. Com isso, interrompeu-se uma trajetória que vinha desde 2005 ampliando a cadeia produtiva do algodão orgânico no semiárido, acompanhando as tendências do mercado de moda. Dessa forma, parte dos incentivos para a produção, e até mesmo a aproximação com empresas compradoras, deixou de ser feita entre 2014 e 2018, levando à desorganização dos grupos de produção que haviam se formado nos territórios (Diaconia, 2019).

Atualmente, os grupos de produção vêm recebendo assistência técnica de diversas organizações não governamentais, financiadas em larga medida pelo programa de matérias-primas sustentáveis da Laudes Foundation (antigo Instituto C\&A), ligada ao mercado de moda. E, com essa retomada, já é possível contabilizar 2.339 famílias cultivando o algodão em consórcios agroecológicos (Tabela 2).

Nessas circunstâncias, a sustentabilidade e a continuidade do processo também dependerão do grau de maturidade e de estruturação dos OPACs, bem como da interatividade dos grupos de produtores nos territórios. Isso implicará implementação de processos de monitoramento e gerenciamento da certificação, em uma condição em que se prevê a ampliação do número de famílias interessadas em aderir aos sistemas agroecológicos. Isso exigirá um investimento na informatização do processo gerencial para aumentar a sua eficácia na coleta e na sistematização de dados, tanto para atender as exigências do Ministério da Agricultura, Pecuária e Abastecimento no processo de certificação quanto para a previsão de safra e consolidação de colheita, essenciais para o fechamento de contratos.

Contudo, como o sistema de produção nos consórcios agroecológicos não se constitui em um pacote tecnológico e depende de processos sociais intensos, a assistência técnica assume um caráter fundamental na mobilização social e manutenção

\footnotetext{
${ }^{26} \mathrm{O}$ mercado de algodão orgânico ainda não faz distinção entre o agroecológico e o orgânico.

${ }^{27}$ Composição de dados da Textile Exchange (2019), Diaconia (2019) e Pedro Jorge Lima (2020).
} 
TABELA 2 - Número de famílias envolvidas na produção de algodão de base agroecológica nos territórios do semiárido nordestino

\begin{tabular}{llc}
\hline Estado & Territórios do Semiárido & Total de famílias \\
\hline Alagoas & Território do Alto Sertão Alagoano (a) & 108 \\
Ceará & Alto Inhamuns (Tauá)(b) & 100 \\
Ceará & Território do Sertão Central Cearense(b) & 150 \\
Ceará & Território dos Inhamuns/Crateús (b) & 150 \\
Paraíba & Polo Sindical da Borborema (Agreste)(c) & 100 \\
Paraíba & RBAAssentamento Juarez Távora e Ass. Coqueiral(d) & 50 \\
Paraíba & Território Cariri Paraibano (a) & 200 \\
Pernambuco & Território do Sertão do Araripe/PE(a) & 660 \\
Pernambuco & Território do Sertão do Pajeú/PE(a) & 74 \\
Piauí & Território da Serra da Capivara/PI(a) & 343 \\
Rio Grande do Norte & Território Sertão do Apodi/RN(a) & 36 \\
Sergipe & Território do Alto Sertão Sergipano(a) & 368 \\
\hline Total & & $\mathbf{2 . 3 3 9}$ \\
\hline
\end{tabular}

FONTE: Os autores.

(a) Contagem realizada no projeto Algodão em Consórcios Agroecológicos (Diaconia, 2019).

(b) Estimativas do coordenador do programa algodão do Esplar.

(c) Estimativas da equipe de assessoria da AS-PTA.

(d) Estimativas da equipe de assessoria da ONG Arribaçã.

das experiências de cultivo em curso. E, portanto, é um elemento que deve ser considerado como essencial para refletir sobre a viabilidade da ação no futuro. Isso porque uma segunda descontinuidade na assistência técnica poderá significar um golpe duro para a expansão da cotonicultura orgânica no semiárido nordestino.

\section{Considerações finais}

Do ponto de vista do processo produtivo, os sistemas de cultivo do algodão, em consórcios agroecológicos no semiárido, podem ser considerados um permanente experimento. A variabilidade de situações climáticas na região impõe desafios a cada novo ciclo produtivo. Além disso, dado que a tecnologia tem componentes sociais importantes, a cada ano se renovam pactos coletivos para a realização de vazios sanitários, coordenação dos plantios de acordo com o calendário local, seleção das sementes para o próximo ciclo e manejo sanitário dos consórcios. Os sistemas de cultivo têm grandes exigências em mão de obra, o que requer investimentos para o desenvolvimento de novos equipamentos, processos e inovações.

A Região Semiárida possui características que impõem um grau maior de incertezas de sucesso da atividade agrícola quando comparada a outros biomas mais úmidos. Diante disso, o desenvolvimento dos demais produtos dos consórcios cumpre papel importante na consolidação dos sistemas de cultivo, ao reduzir os riscos e as oscilações fortes no desempenho de cada cultivo, e também nas eventuais flutuações de preços. Para isso, é fundamental desenvolver competências também nos processos de 
pós-colheita, comercialização e marketing para garantir a agregação de valor ao conjunto da produção, o que implicará articulação com novos mercados. Não obstante, a tendência é o algodão seguir como "carro chefe" dos consórcios por alguns anos. Isso porque o mercado do algodão certificado mostra-se bastante reprimido pela escassez de matéria-prima, dando sinais de que está muito longe da saturação, tornando-o bastante promissor para as famílias associadas aos OPACs.

$\mathrm{O}$ fato é que o algodão do semiárido brasileiro pode voltar a desempenhar um papel central para o desenvolvimento sustentável da região nordeste brasileira, desde que introduzido em consórcios agroecológicos para sua inserção em mercados globais orgânicos e do comércio justo.

\section{Referências}

Albuquerque, F. A.; Arriel, N. H.; Blackburn, R. M.; Santiago, F. S.; Alves, I.; Vale, D.; Guimarães, F.; Cardoso, G.; Alcantara, P.; Feitosa, F.; Cavalcanti, A.; Meireles, A.; Silva, V. Algodão em consórcios agroecológicos: experiência de reintrodução do algodão na agricultura familiar nordestina. São Paulo: ABRAPA, 2011. p. 1735-1739.

Almeida, V.; Parisius, C. Ser mulher num mundo de homens. Serra Talhada: Sactes/DED, 1995.

Amaral, L. História Geral da Agricultura Brasileira: no tríplice aspecto político-social-econômico. 2. ed. São Paulo: Companhia Editora Nacional, 1958.

Andrade, M. C. de. A terra e o homem no Nordeste. 3. ed. Brasília: Brasiliense, 1973.

Araújo Filho, A. A.; Rabelo, J. L .C.; Coêlho, J. D.; Freitas, G. A.; Sena, J. V. C. Caracterização da cadeia produtiva do algodão no semiárido nordestino. Fortaleza: s.n., 2013. 978-85-7791-216-2. (Série Documentos do ETENE nº 32)

Berlim, L. G. Transformações no campo da moda: crítica ética e estética. Rio de Janeiro: s.n., 2016.

Blackburn, R. M. Algodão e alimentos consorciados em roçados agroecológicos: alternativas de produção de alimentos e geração de renda no semiárido. Recife: s.n., 2012.

Boltanski, L.; Chiapello, E. Onovo espírito do capitalismo. São Paulo: WMF/Martins Fontes, 2009.

Câmara, M. A. da. Obras reunidas. Obra coligida e com estudo biográfico por José Antônio Gonsalves de Mello.
Recife: Fundação de Cultura Cidade do Recife, 1982. (Coleção Cidade do Recife, 23)

Cartaxo, W. V.; Guimarães, F. M.; Soares, J. J.; Beltrão, N. E. D. M. Potencialidades da produção de algodão pela agricultura familiar do Nordeste. Campina Grande: s.n., 2008.

CONAB. Série histórica das safras - Algodão. Disponível em: https://www.conab.gov.br/info-agro/safras/serie-historica-das-safras. Acesso em: 20 abr. 2020.

Costa, M. F. A. A institucionalização dos mercados de orgânicos no mundo e no Brasil: uma interpretação. Seropédica: s.n., 2005.

Costa, S. R.; Bueno, M. G. A saga do algodão: das primeiras lavouras à ação na OMC. Rio de Janeiro: Insight Engenharia, 2004.

Diaconia. Projeto algodão em consórcios agroecológicos. Relatório de monitoramento ano 1. Recife: Diaconia, 2019.

Fernandes, M. S.; Ramos, D. P.; Mattos, L. C. Agricultura itinerante e desertificação. In: Agricultura e desertificação. Lisboa: Associação Internacional das Jornadas de Engenharia dos Países de Língua Oficial Portuguesa, 1992. p. $75-100 / 201$.

Gardner, G. F. Travels in the interior of Brazil, principally through the Northern Provinces and Gold and Diamond Districts, during the years 1836-1841. London: Reeve/ Brothers, 1846. 
Haney, P. B.; Lewis, W. J.; Lambert, W. R. Cotton production and the Boll Weevil in Georgia: history, cost of control, and benefits of eradication. Athens: Cooperative Extension, 2009.

Harris, F. A.; Canerday, T. D.; Henry, L. G.; Palmquist, D. L. Working together: roles of private consultants, industry, researchers, extension, and growers. In: King, E. G.; Phillips, J. R.; Coleman, R. J. (Eds.). Cotton insects and mites: characterization and management. 3. ed. Memphis (Tennessee): The Cotton Foundation Publisher, 1996. p. 843-851.

Jerônimo, J. F.; Almeida, F. A. C.; Silva, O. R. R. F.; Brandão, Z. N.; Sofiatti, V.; Gomes, J. P. Qualidade da semente e fibra de algodão na caracterização do descaroçador de 25 serras. Revista Brasileira de Engenharia Agrícola e Ambiental, 18(6), 664-671, 2014.

King, E. G.; Powell, J. E. Propagation and release of natural enemies for control of cotton insect and mite pests in the United States. Crop Protection, 11, 497-506. 1992.

Lima, P. J. B. F. Memórias pessoais sobre o desenvolvimento dos sistemas de produção do algodão em consórcios agroecológicos. [Entrevista] (abril 2020). 2020.

Lima, P. J. B. F.; Oliveira, A. A.; Ponte, A. C. F.; Lima, A.; Oliveira, M. V. Algodão agroecológico: uma experiência no semiárido cearense. Agriculturas, 2(3), 19-22, out. 2005.

Mattos, L. C. M. Um tempo entre secas: superação de calamidades sociais provocadas pela seca através das ações em defesa da convivência com o semiárido. Rio de Janeiro, Tese (Doutorado em Ciências Sociais, Desenvolvimento, Agricultura e Sociedade) - UFRRJ, 2017.

Mawe, J. Travels in the interior of Brazil, particularly in the gold and diamond districts of that country. London: Longman, 1812.

Moreira, J. de A. N.; Freire, E. C.; Santos, R. F. de; Barreiro Neto, M. Algodoeiro mocó: uma lavoura ameaçada de extinção. Campina Grande: CNPA/Embrapa, 1989.
Nunes, L. A. P. L.; Araújo Filho, J. A. de; Menezes, R. I. de Q. Impacto da queimada e do pousio sobre a qualidade de um solo sob caatinga no semiárido nordestino. Revista Caatinga, 19(2), 200-208, 2006.

Ogilvy, S. Developing the ecological balance sheet for agricultural sustainability. Sustainability Accounting, Management and Policy Journal, 6(2), 110-137, 2015.

Palacios, G. Campesinato e escravidão no Brasil: agricultores livres e pobres na Capitania Geral de Pernambuco (1700-1817). Brasília: UnB, 2004.

Practical Action. Building technical capacities agriculture. Disponível em: http://practicalaction.org/building-technical-capacities-agriculture.

Santos, I. C. S.; Wanderley Jr., J. S. A.; Santos, F. N.; Silva, M. N. B.; Gonzaga, L. A. Beneficiamento de algodão orgânico no agreste paraibano. Foz do Iguaçu, s.n., 2009. p. 50-55.

Sidersky, P.; Jalfim, F.; Araujo, E. A estratégia de assessoria técnica permanente do Projeto Dom Hélder Câmara. 2. ed. Recife: PDHC, 2010.

Sousa, G. S. Tratado descritivo do Brasil em 1587 (obra original digitalizada). 2. ed. Rio de Janeiro: Typographia de João Ignacio da Silva, 1879.

Staden, H. Viagem ao Brasil: versão do texto de Marpurgo, de 1957, por Alberto Löfgren. Rio de Janeiro: Officina Industrial Graphica, 1930.

Textile Exchange. Organic cotton market report 2019 Covering production trends and initiative updates from the 2017/18 harvest year. s.1.: Textile Exchange, 2019.

Weid, J. M. V. de. A gênese do projeto tecnologias alternativas. 2013. Disponível em: http://aspta.org.br/2013/05/ 30-anos-de-as-pta-uma-visao-pessoal-parte-i-a-genese-do-projeto-tecnologias-alternativas/. 